\title{
O que Nietzsche leu e o que não leu
}

\author{
Andreas Urs Sommer**
}

\begin{abstract}
Resumo: $\mathrm{O}$ principal objetivo deste artigo é explorar a complexa e multivariada condição de Nietzsche como leitor. Nesse sentido, em primeiro lugar lançam-se luzes sobre suas informações de leitura, nem sempre confiáveis, externadas em sua própria obra, nos fragmentos póstumos, nas cartas, em testemunhos de terceiros, em sua biblioteca preservada e na não preservada, em aquisições e em empréstimos a bibliotecas. Num segundo momento propõemse fases de leitura desde o Nietzsche adolescente, estratégias de leitura, seu processo de libertação e autoestilização como leitor. Já no âmbito das esferas de leituras, aborda-se o Nietzsche leitor de filologia, das ciências, do mundo e da própria cultura. Por fim, ao questionar o modo como Nietzsche foi leitor de si mesmo, acena-se para a questão de como sua atitude de leitura se torna dispositivo para ele próprio pensar e escrever sua obra, fazendo valer a exortação inicial, de que para compreender o Nietzsche filósofo é necessário ter em mente a quem ele está a responder.

Palavras-chave: leitor, fontes, biblioteca de Nietzsche, cultura.
\end{abstract}

* Tradução de Saulo Krieger

** Professor da Universidade de Freiburg, Freiburg, Alemanha.

ORCID https://orcid.org/0000-0002-9215-3172

Correio eletrônico: sommer@adw.uni-heidelberg.de 
Sommer, A. U.

Filósofos pensam. Filósofos escrevem. Mas filósofos leem também? E se sim, o quê? Por que e quanto?

Friedrich Nietzsche é um autor afeito a informações sobre si próprio. Por isso se teria a esperança de se poder muito saber por ele próprio acerca da relação entre a leitura, o pensamento e a escrita.

Entretanto, o fato de não se ter respostas inequívocas à pergunta sobre essa relação, bem como a outras perguntas, complementares, não há de surpreender aqueles que têm em Nietzsche um pensador que está a constantemente experimentar e que recusa respostas definitivas.

Para o leitor movido por interesse sistemático na obra de Nietzsche, tal experiência é fonte inesgotável de frustração, de modo que não raras vezes ela mais acederá à ideia de os caminhos do filósofo serem mesmo todos aporéticos, do que a negará. Já para o leitor de Nietzsche que apreende o pensamento como movimento, essa mesma experiência será uma fonte de felicidade. O mesmo vale para aqueles cuja pergunta por Nietzsche como leitor e não leitor é levada a sério, pois veem aí que o filósofo se põe no contexto de seu tempo, e nisso se o compreendende como alguém que, a exemplo de todo ser vivo-leitor, reage a influências do meio ambiente, sem que nenhuma abordagem blasfema venha a diminuir sua originalidade e sua "relevância filosófica". Pelo contrário: só mesmo aquele que compreende a quem o pensador e escritor Nietzsche está a responder - isto é, basicamente aquele que compreende o que chegou ao conhecimento do Nietzsche leitor - estará em condições de, afinal, compreender a escrita e o pensamento de Nietzsche.

\section{Cenas de leitura e das leituras de Nietzsche}

Ocorre que precisamente as informamções que Nietzsche dá sobre si como leitor são de certo modo sibilinas. Tomemos dois exemplos - um deles do período de juventude do filósofo, outro do período tardio. Em sua "Retrospectiva sobre meus dois anos em

$10 \mid$ Cad. Nietzsche, Guarulhos/Porto Seguro, v.40, n.1, p. 9-43, janeiro/abril, 2019. 
Leipzig" ("Rückblick auf meine zwei Leipziger Jahre") do outono de 1867, ele relata como conseguira, à época de estudante, ao manter-se em "isolamento feliz", "se concentrar". Foi nesse estado de isolamento que, em 1865, num alfarrábio, por acaso veio a deparar com o Mundo como vontade e representação, de Arthur Schopenhauer:

tomei-o nas mãos, como objeto que me era completamente estranho e o folheei. Não sei qual demônio me soprou nos ouvidos: "Leve este livro para casa". De todo modo, foi algo que contrariou meu hábito de não ir com muita pressa na compra de livros. Em casa, com o tesouro adquirido lancei-me no sofá e comecei a deixar aquele gênio energicamente sombrio atuar sobre mim. Ali se tinha cada linha, cada renúncia, cada negação, resignação a gritar, ali eu olhava num espelho no qual eu contemplava o mundo, a vida e a própria alma em desconcertante grandiosidade. [...] A necessidade de autoconhecimento, mesmo de um autodesfazimento me arrebatava com violência; testemunhas daquela reviravolta ainda me são as inquietas e melancólicas folhas de diário daquele período, com suas inúteis autoacusações e olhares desesperados à purificação e à transformação de toda a humanidade (KGW 4:60 [1], 1.513).

O jovem Nietzsche, que aqui olha retrospectivamente para o Nietzsche ainda mais jovem, retrata o episódio como um sacrifício - o sacrifício de uma leitura que o subjugou e lhe virou a vida do avesso. À leitura é atribuída uma força que determina a existência, uma capacidade de converter uma pessoa em outra. No entanto, em sua análise pormenorizada da narrativa da experiência transtornante da leitura de Schopenhauer ele versa também sobre como o alter-ego do estudante estava disposto a tal experiência: Schopenhauer caía em solo fértil, já que o mundo de certo modo já havia desgostado o jovem Nietzsche com "experiências e decepções dolorosas". Se foi tão drástica a vivência de leitura de Schopenhauer, sem uma sensibilidade especial a filosofia pessimista jamais teria caído em solo fértil. Mas o que chama a atenção é não apenas o quanto Nietzsche destaca o significado dessa leitura, mas sobretudo também o quanto, num espaço de dois anos, ele tomou distância de seu eu anterior. A vivência da 
Sommer, A. U.

leitura de Schopenhauer é ironicamente perspectivada como veleidade pós-pubertária, como exaltação realmente doentia. À sua própria visão retrospectiva de 1867, a potência do pessimismo que arrastou consigo o Nietzsche de 1865 aparecia como um acontecimento secular de revelação, tendo-se ali uma vivência de despedaçamento, por mais que estilizada. O Nietzsche do ano de 1867 havia se recuperado pelo menos das consequências patológicas da leitura do ano de 1865. Mesmo assim, o relato não deve ter sido historicamente fidedigno: a afirmação de a obra de Schopenhauer ser a ele "completamente estranha" até o encontro memorável no alfarrabista de Leipzig entra em forte tensão com as circunstâncias, uma vez que referências a Schopenhauer já eram encontradas em anotação da autoria de Nietzsche de alguns meses antes da visita ao alfarrábio, com referência à palestra História Geral da Filosofia, de Carl Schaarschmidt, de quando era estudante na Universidade de Bonn. ${ }^{1}$ E também é nítido o quanto a cena no alfarrábio se encontra modelada por um experiência de leitura anterior, ${ }^{2}$ qual seja, a célebre cena das Confissões (VIII 12) de Agostinho, que, procastinador, caminhava desesperado pelo jardim, quando ouviu a voz de uma criança a lhe dizer "aquieta-te, ó, raivoso;. toma e lê"; nisso, entrando em casa, tomou da Bíblia e na Carta aos Romanos encontrou seu despertar, convertendo-se tanto ao cristianismo quanto a um modo de vida ascético. $\mathrm{Na}$ farsa de Nietzsche, no entanto, está a falar não a voz de Deus, e sim a de um demônio; porém o efeito, que é a conversão à negação da vida, é o mesmo. E considere-se que já em 1867 Nietzsche mostra-se retrospectivamente crítico.

Se esse primeiro exemplo mostra Nietzsche num estado de fascínio que lhe transformou a vida, o eu que fala num segundo exemplo, extraído da terceira seção do capítulo "Por que sou tão

1 Cf. Figl 2007, p. 186 e Hödl 2009, p. 306.

2 Cf. Figl 1984, p. 114.

12 | Cad. Nietzsche, Guarulhos/Porto Seguro, v.40, n.1, p. 9-43, janeiro/abril, 2019. 
esperto", na autogenealogia Ecce homo de 1888, comprova que ele cuidava de manter um trato soberano e distanciado com suas leituras: "No meu caso, toda leitura faz parte de meus restabelecimentos: portanto, do que me desprende de mim mesmo, do que me faz passear por ciências e almas alheias, -- o que não mais levo a sério. A leitura me refaz justamente de minha seriedade" (EH/EH, "Por que sou tão esperto" 3, KSA 6.284). A leitura é distração e não toca de fato no vigoroso indivíduo-pensador, já que todo o essencial ele cria de si mesmo, e com isso todo estímulo exterior vem atuar apenas como perturbação. "Vou eu permitir que um pensamento estranho suba dissimulado por sobre o muro?" Surge daí a impressão de que como criador Nietzsche seria abstinente de leitura. "Já se vai meio ano em que não me vejo com um livro na mão". Essa afirmação é pura e simplesmente falsa: no período em questão, Nietzsche consultou mais de uma dezena de livros, e os explorou em seus escritos. ${ }^{3} \mathrm{O}$ livro que ele então nomeia como um título de cuja leitura ele se recorda, $O s$ céticos gregos (Les sceptiques grecs) de Victor Brochard, tem a honra dessa menção não apenas porque Nietzsche se ocupou dos céticos que ali são enaltecidos, mas sobretudo porque a esse respeito as Laertiana "são bem utilizadas" pelo próprio filósofo, ${ }^{4}$ e aqui se tem em mente seus primeiros ensaios filológicos. Essas referências, por sua vez, são testemunhos do Nietzsche leitor científico, cuja ambição como filólogo era explorar as fontes sobre as quais Diógenes Laércio assentara seu compêndio sobre os filósofos gregos, fazendo-o por meio de minuciosas leituras comparativas. Se Nietzsche ali se refere a si mesmo como um abstêmio da leitura ou mesmo como (quase) não leitor, é como erudito que reflete sobre uma obra secundária de

3 Cf. Brobjer 2008, p. 7 e Sommer 2013a, p. 409-410.

4 No detalhe, Brochard 1887, p. 48 n. 2; sobre o tratado de Nietsche Fontes de Diógenes Laércio (De Laertii Diogenis fontibus) de 1868\1869 (cf. Brochard 1887, p. 122, n. 10 e p. 318 n. 1), bem como sobre as Contribuições sobre as fontes históricas e crítica de Diógenes Laércio (Beiträgen zur Quellenkunde und Kritik des Laertius Diogenes), de 1870, Brochard 1887, p. 87, n. 3; p. 254, n. 4; p. 260, n. 1 e p. 327, n. 1. 
Sommer, A. U.

sua fase de ser humano-leitor. Esse erudito, e com isso também o eu anterior de Nietzsche, no Ecce homo - desta feita na oitava seção do capítulo "Por que sou tão esperto" - será alvo de uma profunda crítica: "O erudito que basicamente não faz mais do que 'revirar' livros - o filólogo [o faz em] uns duzentos por dia, em cálculo modesto - acaba por perder totalmente a faculdade de pensar por si" (EH/ EH, "Por que sou tão esperto" 8, KSA 6.292-293). Ele meramente reage a um estímulo externo. O Nietzsche tardio dá a impressão de ter advindo como pensador sem quaisquer desses estímulos. É de se pensar no quanto essa injunção causal estaria distante da experiência de ser subjugado por um livro, experiência por ele reportada acerca do alfarrábio de Leipzig. Ocorre que, entre a vã difamação dos estímulos e a realidade histórico-filologicamente detectada do leitor Nietzsche sempre ávido por estímulos abre-se um pavoroso abismo. A narrativa da resistência à subjugação do leitor Nietzsche de 1888 é igualmente estilizada, preparada tendo em mente outros leitores, assim como o foi a narrativa da euforia pela subjugação do leitor Nietzsche de 1867.

A autoimagem construída no Ecce homo por certo que de modo algum impede o próprio Nietzsche de subjugar seus próprios leitores, na expectativa de que não se mostrem tão resistentes a estímulos como ele ou seu ideal. No Prefácio à Genealogia da moral, Nietzsche como que exige dos leitores de seus próprios escritos "exercer a leitura como arte", como uma prática para a qual "é preciso ser quase uma vaca e em todo caso não um 'homem moderno': o ruminar" (GM/ GM, "Prólogo", 8 KSA 5.256). Enquanto no Ecce homo a prática ,ruminadora" dos eruditos é ironizada (EH/EH, "As extemporâneas" 3, KSA 6.320-321), a referida passagem da Genealogia é a única em que o ruminar é alçado à condição de máxima hermenêutica, de instrução para a vida. A identificação da leitura à ruminatio na interpretação alegórica do terceiro livro de Moisés e do quinto livro

14 | Cad. Nietzsche, Guarulhos/Porto Seguro, v.40, n.1, p. 9-43, janeiro/abril, 2019. 
de Moisés, 14,6 conta entre os mais antigos topoi da hermenêutica religiosa. Nietzsche deparou com esse topos na leitura de Cristoph Lehmann: "Devorar livros em vez de ruminar nada tem de salutar e é uma crueldade para com o cérebro."5.

A própria estratégia de escrita de Nietzsche em sua obra tardia tem em vista impedir que seus escritos fossem recebidos como mera literatura, e desse modo como mera "recreação", e que assim atuassem como literatura: enquanto no Ecce homo o eu falante desprestigia o que dele se lê como forma de recreação, o que do próprio eu é escrito para o seu leitor deve proporcionar, em vez de recreação, um despertar: nessa leitura os leitores devem exectuar algo novo, iniciar vidas novas, transvaloradas.

Ocorre que o orgulhoso distanciamento das próprias experiências de leitura não deve induzir ao erro de se pensar que tais experiências de leitura não seriam as verdadeiras experiências de mundo, que subjaziam ao filosofar de Nietzsche. $\mathrm{O}$ mundo de Nietzsche é em ampla medida um mundo lido, um mundo conquistado através dos livros. A leitura é seu acesso privilegiado ao mundo, por mais que ele queira dar a impressão de que seus conhecimentos teriam sido obtidos da observação ou da experiência de mundo, da comunicação discursiva ou da inspiração. O fundamento granítico de seu filosofar é a leitura. Ele é um filósofo de livros exemplar, um filósofo-leitor. E nessa medida, também um filósofo leitor cuja originalidade reside precisamente em se valer de livros de outros como campos de experimentação, e de valer-se de seus próprios livros em debate contínuo com os dos outros, para com isso se distinguir dos leitores superficiais. Se é a tal ponto livre e desembaraçado o modo como se relaciona com o que encontra de outros - frequentes vezes sem os nomear -, nem por isso ele pode ser tomado como um plagiador no

5 Cf. Lehmann 1879, p. 52. 
Sommer, A. U.

sentido corrente: ele transforma o que lê e se mostra um pensador que reage a constelações de leituras de um modo que é em alta medida variável de caso a caso. Para compreender o que Nietzsche opera, e o que pensa acerca disso, faz-se crucial fundamentar o que ele lê e o que faz do que lê.

\section{Fontes para Nietzsche como leitor e não leitor}

Sendo nossa intenção a de rastrear Nietzsche como leitor - e apurar não apenas o que ele leu, mas também o que não leu -, temos diante de nós diferentes vias. Passemos em primeiro lugar ao mais óbvio, qual seja, as

1. Obras de Nietzsche. Suas obras supostamente dariam informações abrangentes acerca do que o autor leu. E ao fazêlo, o resultado é impressionante: segundo todas os comentários abalizados, apoiados em leituras, ao que tudo indica Nietzsche seria amplamente versado na filosofia e na literatura de todas as épocas, nas ciências naturais e do espírito, em teologia, medicina e jurisprudência. Por exemplo, é de maneira aberta e sincera que ele dá informações sobre o que, como e por que filósofos célebres pensaram e escreveram e sobre onde pisaram em falso - ou sobre como se deve apreciar, esteticamente e em seu universo cultural, as mais jovens expressões beletrísticas. Sobre isso podemos arrolar dois exemplos. O primeiro, em Nietzsche contra Wagner ele nos faz lembrar da palavra de Feuerbach sobre a "sensualidade saudável" (NW/NW, "Wagner como apóstolo da castidade" 3, KSA 6.431), lembrança esta que num escrito do fragmentos póstumos de 1886187 inclui: "sensualidade saudável e fresca de Feuerbach / fundamentos $d a$ filosofia do futuro' 1843. \ contra ,a filosofia abstrata"“ (Nachlass/ FP, 7 [4], KSA 12.261). Ora, infelizmente Feuerbach jamais proferiu algo como "saudável e fresca" ou mesmo "sensualidade

16 | Cad. Nietzsche, Guarulhos/Porto Seguro, v.40, n.1, p. 9-43, janeiro/abril, 2019. 
saudável". O conhecimento supostamente acurado de Nietzsche sobre Feuerbach remete à segunda parte do volume destinado a Descartes da autoria de Kuno Fischer, História da nova filosofia (Geschichte der neuern Philosophie), onde, com referência aos Fundamentos da filosofia do futuro (Grundsätze der Philosophie der Zukunft) afirma: "Desde Feuerbach a 'filosofia abstrata' tem se convertido em palavra de ordem, à qual se contrapõe outra palavra de ordem, da 'sensualidade 'saudável e fresca' como diretriz da filosofia."6 Nietzsche produz uma citação ocasionada por uma leitura apressada de Kuno Fischer.

Em segundo lugar: frequentes vezes, referências a outros autores nas obras de Nietzsche sugerem um conhecimento haurido do que seriam suas próprias leituras de fontes originais, com as quais o filósofo, no entanto, travou contato apenas de segunda mão. Isso vale não apenas para os clássicos, mas também para autores seus contemporâneos. É nesse sentido que a já citada terceria seção do capítulo "por que sou tão esperto" do Ecce homo dá a impressão de que Nietzsche teria se ocupado intensamente dos livros dos "senhores Paul Bourget, Pierre Loti, Gyp, Meilhac, Anatole France, Jules Lemaître" - "ou, para destacar um de raça forte, um autêntico latino ao qual sou especialmente afeiçoado, Guy de Maupassant" (EH\EH, "Por que sou tão esperto" 3, KSA 6.285). De correto aí se tem que, ao valer-se dos estudos críticos de Paul Bourget e Jules Lemaître, Nietzsche teria explorado os outros senhores, e além disso a leitura de artigos de jornal deixaram-no em condições de mimetizar informações a respeito. Não há como comprovar a leitura efetiva dos trabalhos beletrísticos em questão. ${ }^{7}$

Ambos os exemplos fazem ver: tomadas em si mesmas, as obras de Nietzsche são informantes pouco confiáveis se se quiser ter conhecimento do que ele efetivamente leu - e do que não leu. E quanto ao que se pode ter então nos

6 Cf. Fischer, K. 1865, parte 2, p. 561.

7 Cf. Sommer, A. U. 2013a, p. 414-417

Cad. Nietzsche, Guarulhos/Porto Seguro, v.40, n.1, p. 9-43, janeiro/abril, 2019. 
Sommer, A. U.

2. fragmentos póstumos de Nietzsche? Sob essa rubrica encontra-se reunido material manuscrito altamente heterogêneo. E grande parte desse material de fato nos oferece uma visão direta dos hábitos de leitura de Nietzsche. Nesse sentido, entre os fragmentos de 1875 encontra-se um excerto bastante longo, contendo apontamentos críticos sobre o livro $O$ valor da vida (Der Werth des Lebens [1865]), de Eugen Dühring (Nachlass/ FP, 9 [1], KSA 8.131-181) e a eles o filósofo pôde recorrer sempre que mais tarde veio a se referir a Dühring. Mas se se procurar aí um excerto de uma fonte de Nietzsche, de modo algum se vai encontrar o que se procura. Da mesma forma, entre os fragmentos póstumos de 1887 há uma anotação bastante longa, a cavoucar profundamente nos escritos de Spinoza, a detectar aspectos de seu pensamento que, relegados a escritos periféricos do grande pensador substancialista, revelaram-se determinantes na obra publicada de Spinoza (Nachlass/FP 9 [1], KSA 8.131-181). Por mais que isso tenha proporcionado a gerações de pesquisadores o ensejo para louvar a profundidade dos estudos de Nietzsche sobre o filósofo holandês, de há muito se tem por líquido e certo que Nietzsche não leu nenhuma linha de Spinoza no original: a anotação é um alentado excerto da História da filosofia nova (Geschichte der neuern Philosophie) de Kuno Fischer (Nachlass/FP 7 [4], KSA 12.259-270). Listas de títulos de livros, frequentemente encontradas nos fragmentos póstumos, são indícios valiosos de leituras possíveis, sem porém conter nenhuma comprovação de leituras efetivamente realizadas: estaria Nietzsche com a intenção de comprar os livros assinalados, quereria ele tomá-los de empréstimo na biblioteca? E teria chegado a fazê-lo?

Mas também o contrário é possível: na segunda versão do arremedo infeliz e malfeito de $A$ vontade de potência, resultado de 18 Cad. Nietzsche, Guarulhos/Porto Seguro, v.40, n.1, p. 9-43, janeiro/abril, 2019. 
uma compilação do Nietzsche-Archiv de Weimar, sob o número 368 encontra-se um aforismo supostamente atribuído ao filósofo, ${ }^{\mathbf{8}}$ pautado por um registro do espólio do período 1886\1887:

A compaixão é um desperdício de sentimento, um parasita nocivo da saúde moral, "e é impossível que se tenha o dever de aumentar o mal no mundo". Quando se faz o bem por compaixão, faz-se-o na verdade a si mesmo, e não ao outro. A c〈ompaixão〉 não reside em máximas, mas em afetos: ela é patológica; o padecimento do outro se oculta em nós, a compaixão é um contágio (Nachlass/FP 7 [4], KSA 12.268. Nietzche retomará essas ideias no aforismo 7 de $O$ anticristo: KSA 6.173).

O que se ouve como um pensamento original de Nietzsche é na verdade uma adaptação da Metafísica dos costumes de Kant (teoria das virtudes, "A sensação compartilhada é na verdade um dever", § 34). Mas também essa obra Nietzsche não leu, e sim dela tão-somente se serviu no volume dedicado a Kant no História da nova filosofia de Fischer. Ali se tem, num emprego bastante livre do modelo de Kant:

A participação proveitosa serve a tudo, a mera compaixão, para nada. [...] O sofrimento do outro contagia. A compaixão nada mais é do que um tal contágio, um sentimento patológico, que nada tem de prático. Ajuda em alguma coisa se sinto compaixão? Do que ajuda se em vez de um se defrontar com o flagelo, agora dois padecerem por ele? O primeiro sofre de verdade, o outro na imaginação. Para que serve o sofrimento imaginário? Assim, aos olhos de Kant a compaixão aparece como um desperdício de sentimento no tocante à saúde moral, como um parasita a que se tem de alimentar. "Um dever impossível há de ser o de aumentar o mal no mundo". A compaixão é um tal aumento desnecessário. Ajudar onde e à medida que se possa; onde não se puder, que não se deixe afeminar por sentimentos imaginados, de modo a incapacitar-se à ação: essa é a moral de Kant a contradizer a compaixão. A compaixão é patológica, não reside em máximas, e sim em afetos. ${ }^{9}$

8 Cf. Nietzsche 1911, vol. 15, p. 406.

9 Cf. Fischer 1860, vol. 2, p. 271-172. 
Sommer, A. U.

Em edições posteriores, Fischer se vale justamente da expressão que Nietzsche veio a copiar, da compaixão "como um parasita nocivo à saúde moral". 10 No trato com os fragmentos póstumos, o que bem se pode ter é o intérprete Nietzsche a afetar uma originalidade que o próprio teor do texto não exigiria: em seus cadernos de anotações, o filósofo deixa de caracterizar como citação o que é citação. Desse modo, também no trato com o espólio como fonte para a atitude de leitura de Nietzsche faz-se necessária alguma cautela. Talvez mais confiança devam receber

3. As cartas de Nietzsche. E de fato: numerosas cartas falam sobre livros - algumas delas, para membros da família e amigos, são mais desejos de aquisição de livros e pedidos de encomenda de livros. Em outras, experiências de leitura são tematizadas pormenorizadamente, por exemplo na carta de 31 de maio de 1885 a Franz Overbeck, onde se trata justamente do livro que ensejara o modo como Nietzsche narra seu despertar para Schopenhauer em 1867: "Li agora, para me distrair, as Confissões de s〈anto〉 Agostinho, lamentando muito não estares aqui. Ah, essa retórica antiga! Quão falsa e atordoante! [...] Neste livro, ademais, vê-se o cristianismo em suas entranhas: com relação a isso, ponho-me com a curiosidade de um médico e fisiológo radical" (KSB 7.34). ${ }^{11}$ No entanto, nenhum exemplar das Confissões foi encontrado entre os livros de Nietzsche: não está claro como e onde ele poderia tê-lo adquirido. E em caso semelhante, quatro anos antes, em 30 de julho de 1881, o filósofo teria comunicado a Overbeck: "Estou de todo estupefato, maravilhado! Tenho um precursor, e que precursor! Eu não conhecia quase nada de Spinoza: que eu seja agora impelido para ele é um ato do instinto“" (KSB 6.111) Nietzsche

10 Cf. Fischer 1889, parte 2, p. 192.

11 Overbeck era íntimo conhecedor de Agostinho, $c f$. Sommer 1998a. Sobre Nietzsche e Agostinho, cf. Sommer $2013 \mathrm{~b}$.

20 | Cad. Nietzsche, Guarulhos/Porto Seguro, v.40, n.1, p. 9-43, janeiro/abril, 2019. 
então passa a referir aspectos em que ele convergia com Spinoza, esquecendo de mencionar ao amigo que devia a sua compreensão não à leitura de originais, mas precisamente a Kuno Fischer. Portanto, também os documentos provenientes do ego-Nietzche, que são as cartas do filósofo, nem sempre são garantes confiáveis. E isso tanto mais vale para os

4. Relatos sobre leituras de Nietzsche em testemunhos de terceiros. Por certo que tais relatos são problemáticos, precisamente porque não raro residem em lembranças ou num "ouvi dizer" de caráter impreciso, e por vezes eles próprios perseguem uma agenda que em alguns casos pode ser traiçoeira. Por isso, em razão de controversos testemunhos de contemporâneos terem sido contestados a respeito, já de há muito não se pode saber em que medida Nietzsche travou contato com o solipsismo de Max Stirner e por qual via teria por ele se inspirado afinal, Stirner jamais foi cidado nos escritos do espólio. ${ }^{12}$ Outros testemunhos deixam de apontar para o cerne do próprio pensar de Nietzsche, seja para negar qualquer inspiração, seja para absolvê-lo de qualquer incorporação, mas são bastante elucidativos quanto ao modo como ele se apropriou de certos conhecimentos de leitura sem necessariamente ter lido. Até seu afastamento como professor, em 1879, Nietzsche foi hóspede frequente do casal Overbeck. Ida Overbeck relata: “À época ele se ocupava do problema de uma nova moral. Meu marido lia em voz alta, traduzindo ensaios de Saint-Beuve de forma improvisada, pois Niezsche não falava francês. Nietzsche era daqueles moralistas aristocráticos e já naqueles anos admitia, como hoje circula entre nós, ser pouco lido e não conhecer muita coisa."13 Foi expressamente necessário Franz Overbeck ter improvisado uma transposição do Causeries du lundi de

12 Cf. Laska, 2002.

13 Cf. Overbeck, 1908, p. 237. 
Sommer, A. U.

Saint-Beuve para o alemão, uma vez que os conhecimentos que Nietzsche à época tinha do francês eram ainda parcos para seguir uma leitura em voz alta na língua. Foi Sainte-Beuve que proveu a Nietzsche o impulso para um contato duradouro com a literatura francesa dos séculos XVII e XVIII. A partir das horas de leitura compartilhada pouco a pouco passou a vicejar um projeto de livro para o qual já não era Franz, e sim Ida Overbeck que se ocupava de traduzir algumas Causeries do Siècles des Lumières. A participação do próprio Nietzsche era intensa na escolha de textos e no contato com os editores, aos quais sugeria a publicação. ${ }^{14}$ Quando finalmente, em $18 \mathrm{de}$ agosto de 1880, teve em mãos o volume pronto e acabado, de pronto descreveu a Ida Overbeck suas primeiras impressões: "Há uma hora, querida professora, recebi o 'homem do século XVIII“, passei a folheá-lo e vi esta e aquela boa palavra e tanto e tanto mais por trás de cada boa palavra! Encanta-me, ao mesmo tempo em que sou tomado pelo sentimento de uma privação inexprimível e profunda. Creio ter chorado, e seria mesmo o caso de aventar se este pequeno livrinho não há de estimular sensação do mesmo tipo em muitos outros" (KSB 6.35). Assim, em se tratando do contato de Nietzsche com Saint-Beuve, têm-se os relatos testemunhais a comprovar uma leitura, ainda que num primeiro momento não se tratasse de uma leitura com os próprios olhos, mas a recepção de uma leitura em voz alta. E diga-se, em face das notórias dores de cabeça de Nietzsche e de seus problemas de visão, era frequente ele receber textos pela via da leitura em voz alta. Mas e quanto à

5. Biblioteca preservada de Nietzsche? ${ }^{15}$ A condição dos pesquisadores das leituras de Nietzsche parece bastante

14 Com detalhes a esse respeito $c f$. Sainte-Beuve 2014, p. 22-30.

15 Um índice (quase completo) é proporcionado por Campioni / D’Torio / Fornari / Fronterotta / Orsucci 2003 (a esse respeito, de Paolo D'Iorio: "História da biblioteca de Nietzsche e seus registros",

22 | Cad. Nietzsche, Guarulhos/Porto Seguro, v.40, n.1, p. 9-43, janeiro/abril, 2019. 
confortável: afinal, graças à incansável atividade de coleta e manutenção da irmã, e de seu arquivo, boa parte do acervo pessoal de livros se encontra conservada. Se de outro modo teriam um destino incerto, centenas de volumes encontram-se hoje conservadas na Anna Amalia Bibliothek, em Weimar, estando ali catalogados e acessíveis à pesquisa. Esses livros cobrem toda a extensão dos interesses de Nietzsche - títulos da filosofia e da beletrística, história e filologia, etnologia, arte e música, ciência da religião e teologia encontram-se igualmente representados, assim como obras de economia e ciências naturais, ou de medicina e psicologia. Por certo que a biblioteca preservada - exceção feita a volumes eventualmente extraviados - não será imagem fiel das leituras de fato realizadas por Nietzsche. Por um lado, ele leu uma série de livros que não possuiu. Por outro, de modo algum leu todos os livros que possuiu. Em muitos não há o menor vestígio de leitura. Outros se encontram completamente intactos - estes por certo não estão entre as obras mais importantes da história das ideias, por exemplo, $O$ ensino do canto na escola pública (Der Gesangsunterricht in der Volkschule (1879), de Frierich Grells, A tectônica da montanha de São Gotardo (Der Gebirgsbau des St. Gotthard) (1875), de Albrecht Müller, A importância do Parsifal de Wagner em e para nosso tempo (The Significance of Wagner's Parsifal in and for our Times) (1884), de Eduard Schlaeger, mas também o Conversas de Phocion sobre a relação entre a moral e a política (Entretien de Phocion sur le rapport de la morale et de la politique) (1877), de Mablys. Outras obras apresentam vestígios de leitura em pequenas partes, como se a leitura o tivesse cansado ou como se o interesse se reduzisse

p. 33-77); para aspectos individuais, $c f$. D Iorio 1999, Fornari 2011 e Montinari 2014. Um projeto internacional de pesquisa tornará a Biblioteca Nietzsche online de livre acesso, com alguns dos trabalhos ali presentes sendo providos de comentários; a esse respeito ver: https://www.philosophie. uni-freiburg.de/seminar/professur_sommer/nietzsche 
Sommer, A. U.

a poucas páginas - nessa categoria se encontram as Obras selecionadas (Ausgewählte Werke) (1874), de Hölderlin, os Fundamentos da estética (Grundzüge der Aesthetik) (1884), de Lotze, Lienhard e Gertrud (Lienhard und Gertrud) (s.d.) e também Die Edda (s.d.), de Pestalozzi. O pesquisador das leituras de Nietzsche pode ainda uma vez se mostrar grato por ele ter tido o cuidado de deixar marcas de leitura: uma série de volumes apresenta em muitas partes, além de orelhas de burro, numerosos assinalamentos. Porém, anotações às margens das páginas com frequência não são muito convidativas à interpretação: por exemplo, uma "orelha" quíntupla em uma página de $A$ irreligião do amanhã (L'irréligion de l'avenir) (1887), de Jean Marie Guyau, ou um "boi" numa página do Os fatos da ética (Die Thatsachen der Ethik (1879), de Herbert Spencer. ${ }^{\mathbf{1 6}}$ Muitas glosas são, um pouco mais ou um pouco menos, comentários filosóficos pormenorizados, que merecem ser considerados como a constituir seu espólio filosófico. Por exemplo, quando na margem da página ele tece um comentário sobre o seguinte enunciado "só se tem o conceito corrreto de força quando se a conhece como aspiração ao desdobramento", no Sobre as causas aparentes e efetivas (Ueber die scheinbaren und die wirklichen Ursachen $)^{17}$ de Drossbach: "vontade de potência", digo eu. ${ }^{18} \mathrm{Um}$ encadernador por demais zelozo certamente deve ter eliminado esforços de decifração da parte de Nietzsche: na reencadernação de diversos volumes muitos blocos de folhas foram cortados, com anotações de margem tendo sido parcialmente cortadas. Além disso, há casos em que uma leitura encontra-se bem documentada, mas o exemplar do livro em questão na biblioteca

16 As páginas encontram-se reproduzidas em Campioni/D`Iorio/Fornari/Fronterotta/Orsucci 2003, p. 274 e 569.

17 Cf. Drossbach 1884, p. 45. O sublinhado é de Nietzsche.

18 Cf. Campioni/D’Torio/Fornari/Fronterotta/Orsucci 2003, p. 200.

24 | Cad. Nietzsche, Guarulhos/Porto Seguro, v.40, n.1, p. 9-43, janeiro/abril, 2019. 
não apresenta nenhum vestígio de leitura. É o caso de $O s$ céticos gregos (Les sceptiques grecs) de Victor Brochard, que, segundo indicação do Ecce homo foi intensamente estudado. Teria Nietzsche se valido de outro exemplar, que por algum motivo teria sido excluído de entre seus livros? Assim sendo, a biblioteca preservada de Nietzsche de modo algum traz uma relação precisa entre livros possuídos e leituras feitas; e com bastante frequência questionamentos se dirigem

6. à biblioteca não preservada de Nietzsche. ${ }^{19} \mathrm{O}$ que se encontra preservado em Weimar é apenas parte dos livros que ele possuiu ao longo de sua inconstante vida. Após a aposentadoria como professor da Basileia, teve de abdicar de uma biblioteca particular clássica de estudioso, mas a partir dali, como deixasse de ter domicílio fixo, passou a ter livros enviados, conforme suas necessidades, aos diferentes endereços em que passou a se estabelecer. Também acontecia de ele vender ou enviar livros. Alguns deles, que a Elisabeth-Föster-Nietzsche pudessem parecer moralmente ofensivos, teriam sido por ela secretamente suprimidos - por exemplo o Do amor (De l'amour), de Stendhal. ${ }^{20} J a ́$ sobre outros títulos ela afirmou que um dia tinham estado lá - um deles seria algo como "as obras de Gobineau" ("die Werke von Gobineau"). ${ }^{21}$ Desse último não há nenhum tipo de comprovação - e supõe-se que os conhecimentos por Nietzsche de Gobineau lhe teriam chegado de maneira secundária. ${ }^{22}$ Muitos títulos devem ter se extraviado - e jamais reaparecido, uma vez que Nietzsche quase sempre se mostrava negligente quanto a identificar os livros com seu nome. Mesmo assim, por meio de notas fiscais de livrarias

19 A esse respeito, $c f$. Campioni 2006.

20 Cf. Campioni/D`Iorio/Fornari/Fronterotta/Orsucci 2003, P. 34.

21 Cf. Campioni/D’orio/Fornari/Fronterotta/Orsucci 2003, P. 45.

22 Como abordagem crítica a esse respeito, $c f$. Schank 2000, p. 436. 
Sommer, A. U.

eventualmente se tem informação do que ele chegou a comprar - e também sobre o que ele fez retornar ao livreiro sem ter lido ou tendo consultado como material de pesquisa - por exemplo, uma edição da Ética de Spinoza em 1875, cujo título não se encontra entre seus livros. Em face da contínua mobilidade do filósofo, é preciso contemplar ainda um último grupo de fontes:

7. Os empréstimos em bibliotecas por Nietzsche, suas visitas a livrarias e cafés. Há muitos livros que Nietzsche não queria ou não podia comprar, e não obstante ele efetivamente os leu. Em seu período como filósofo de vida itinerante, não raro era em livrarias e bibliotecas que ele podia se manter atualizado quanto a lançamentos editoriais; em cafés havia jornais e periódicos à disposição, e ele os lia, não obstante a declarada inclinação contra o jornalismo. Reconstruir essas leituras é algo que só se pode fazer de maneira pontual, e nos casos em que se encontram conservados registros de empréstimo em bibliotecas. Desse modo se tem que em maio e junho de 1887, da biblioteca da cidade de Chur ele retirou a História da cultura em seu desenvolvimento natural até o presente (Culturgeschichte in ihrer natülichen Entwicklung bis zur Gegenwart) (2ª edição, 1876-1877), de Friedrich von Hellwald, A Alta-Engandina em sua influência sobre a saúde e sobre a vida (Das Oberengadin in seinem Einfluss auf Gesundheit und Leben) (1877), de Johann Melchior Ludwig, a História da civilização na Inglaterra (Geschichte der Civilisation in England) (4- edição, 1870), de Henry Thomas Buckles, e volumes da História da nova filosofia, de Fischer. ${ }^{23}$ Estamos perfeitamente a par dos empréstimos por Nietzsche junto a biblioteca da Universidade da Basileia entre os anos de 1869

23 Carta da Biblioteca do Cantão de Graunbünden de 31 de julho de 2002, a indicação é cortesia de Francisco Arenas-Dolz.

26 | Cad. Nietzsche, Guarulhos/Porto Seguro, v.40, n.1, p. 9-43, janeiro/abril, 2019. 
até 1879. ${ }^{24}$ Mas também aqui a prudência se faz necessária: empréstimos aparentemente repetidos em geral documentam apenas que Nietzsche retirou um livro e que o bibliotecário o emprestou para aquele semestre. Também salta aos olhos a quantidade de empréstimos de títulos em filologia. $\mathrm{O}$ que se pode supor é que amigos, aliados e também, possivelmente, estudantes se abasteciam de livros da biblioteca, livros que o próprio Nietzsche consultava. Por isso, os empréstimos na Basileia da parte de, por exemplo, Heinrich Köselitz e Heinrich Romundt deveriam bem ser verificados.

A quem deseja ter o Nietzsche leitor diante dos olhos faz-se aconselhável procurar não apenas em algum dos setes campos assim enumerados, afinal estes, tomados em si mesmos, não proporcionam informações conclusivas sobre o que Nietzsche leu e não leu. Só mesmo se se posicionar os diferentes campos em mútua relação é possível obter uma imagem em certa medida confiável. Ocorre que esse quadro faz-se necessariamente fragmentado - a "biblioteca ideal" de Nietzsche ${ }^{25}$ continua a ser uma ideia regulativa, e emulá-la não obstante traz algo de gratificante a todo aquele que desejar compreender Nietzsche.

\section{Fases de leitura, estratégias de leitura e esferas de leitura}

Ao longo da vida, Nietzsche leu coisas diferentes de modos diferentes. Como tendência geral pode-se assegurar que ele pouco a pouco passava a se desprender da norma que prescreveria o que lhe seria apropriado como leitura - primeiramente como futuro pastor, depois como filólogo profissional -, e isso fez com que se tornasse um

24 Cf. Crescenzi, 1994.

25 Cf. Montinari 1982, P. 6 e Treiber 1996. 
Sommer, A. U.

leitor altamente criativo e altamente seletivo. Seu desenvolvimento como leitor pode ser desmembrado em cinco fases:

1. Nietzsche como leitor mantido a rédea curta: como único descendente de duas dinastias de pastores, Nietzsche aprendeu a ler com o auxílio da Bíblia traduzida por Martin Luther, herdada do pai, que ele usou durante toda a vida. ${ }^{26}$ Livros devocionais como o Histórias bíblicas organizadas segundo o ano litúrgico (Biblische Historien nach dem Kirchenjahre geordnet) (1852), de Franz Ludwig Zahn, que com muitas marcas de leitura se conservaram entre os livros de Nietzsche, vêm complementar a sua imagem de leitor devoto em criança, que aplicadamente assimilava o que lhe era empurrado e com isso satisfazia as expectativas que lhe eram imputadas, de um dia subir ao púlpito como pastor luterano. A inclinação religiosa da casa de Nietzsche reproduziu-se nas escolas pelas quais passou quando jovem, em Naumburg: no Domgymnasium de Naumburg, que frequentou de 1855 a 1858, a religião era, por óbvio, a primeira das ciências, e de modo correspondente era ensinada de modo intensivo, ${ }^{\mathbf{2 7}}$ mas com duas horas semanais a menos em comparação com as dez horas do latim ou com as seis do grego - e observe-se, aliás, que o jovem Nietzsche tinha o ensino religioso por algo "lamentável". ${ }^{28}$ É evidente que para ser aprovado ele tinha de realizar leituras escolares também nas outras disciplinas - ou seja, em alemão e nas línguas antigas. A partir de 1858 sua biblioteca pessoal começou a assumir uma primeira conformação, pela qual títulos de história, mesmo de cunho filosófico-histórico (a História da humanidade [Geschichte der Menschheit], 1787, de Isaak

26 Cf. Sommer 2008.

27 Cf. Figl 2007, p. 19.

28 Cf. Brobjer 1999, p. 308 e 306.

28 | Cad. Nietzsche, Guarulhos/Porto Seguro, v.40, n.1, p. 9-43, janeiro/abril, 2019. 
Iselin) perfilavam-se entre clássicos gregos como Homero, Eurípides e Xenófanes, clássicos alemães como Lessing e Schiller, o Gato Murr, de E.T.A. Hoffmann, a História da vida (Lebensgeschichte) de Jung-Stillings, obras de Körner, Hauff, Seume, Lenau e Immermann. E com Shakespeare, Laurence Sterne, Cervantes e Tasso, também um horizonte da literatura mundial lentamente começava a se desenhar. ${ }^{29}$ Mas entre as leituras que logo viriam a inspirar as próprias tentativas poéticas do jovem nada se encontra que pudesse surpreender os orientadores pedagógicos. Tratava-se bem do plano de leitura normal de um ginasiano ávido pelo saber.

2. Autolibertação e autoestilização como leitor. Com a mudança para a célebre Internatsschule Schulpforta, em 1858, Nietzsche começou a se emancipar intelectualmente. A disciplina escolar era ali tão rígida, e de tal maneira a instituição idealizara a educação dos pupilos para formá-los como leitores autônomos e como doutos pensantes, que essa postura deve tê-los feito trilhar o seu próprio caminho pelo universo da cultura escrita. Sob essas premissas e amparado por uma impressionante biblioteca escolar, Nietzsche passou a seguir o seu próprio caminho como leitor. Um primeiro exemplo: em 1861 ele leu o A essência do cristianismo de Feuerbach, de quem os Pensamentos sobre morte e imortalidade foi obra arrolada numa lista de desejos de presente de aniversário (KGW I 2:11 [24], p. 307).É possível que a mãe tenha tomado esses livros, de títulos insuspeitos, por alguma literatura devocional e com eles presenteado o filho - os títulos não foram mantidos entre seus livros. Seja como for, numa carta a Gustav Krug e Wilhelm Pinder, de 27 de abril de 1862, ele afirma que a humanidade reconhece "em si o início, o meio, o fim da religião"“(KSB 1.202) - sem

29 Uma tabela que traz essas primeiras leituras é encontrada em Brobjer 1999, p. 315-222. 
Sommer, A. U.

citar o nome de Feuerbach. Um segundo exemplo é ainda mais picante: em outubro de 1861, pela disciplina de alemão, Nietzsche teve de escrever um trabalho de casa sobre um poeta seu favorito. Escolheu Hölderlin e teve ouvir do professor, o eminente germanista August Koberstein, após a correção: "Ao autor deste trabalho eu daria o conselho amigo de se ater a um poeta mais saudável, mais claro, mais alemão". 30 Mais tarde, a pesquisa Nietzsche se escandalizaria com esse juízo e atribuiria a Nietzsche a descoberta, por iniciativa própria, de um Hölderlin à época quase esquecido. E manifestou anuência ao relato de que o ginasiano teria escrito um ensaio de grande originalidade sobre um poeta com que teria se sentido íntima e profundamente aparentado. Entrementes, a pesquisa de fontes fez ver que que tal ensaio, que se supunha ser inteiramente de autoria do próprio Nietzsche, nada mais seria do que um plágio textual de amplas passagens de um escrito biográfico de William Neumann (Moderne Klassiker: Deutsche Literaturgeschichte der neueren Zeit in Biographien, Kritiken und Proben: Friedrich Hölderlin [Clássicos modernos: História da literatura alemã dos novos tempos em biografias, críticas e provas: Friedrich Hölderlin, 1859), que Nietzsche possuía e lhe teria sido enviado pela irmã, de Naumburg. ${ }^{31}$ Portanto, o jovem aparentemente tão genial de modo algum hesitou em, por conta da necessidade, adornar-se com pena alheia.

3. O leitor da disciplina filologia. Como estabelecimento de formação dotado da pretensão de formar uma elite, a escola de Pforta provia seus formandos com o instrumental filológico próprio para elucidar criticamente todo texto e ao mesmo

30 Citado segundo JANZ 1978, vol. 1, p. 80.

31 Brobjer 2001.

30 | Cad. Nietzsche, Guarulhos/Porto Seguro, v.40, n.1, p. 9-43, janeiro/abril, 2019. 
tempo se perguntar por seu sentido histórico geral. O quão bem-sucedido foi esse objetivo educaional é algo que se mostra no trabalho de conclusão de curso redigido em latim, o Sobre Teógnis de Megara (De Theognide Megarensi). Ali Nietzsche apresenta o poeta do período arcaico tardio como "um junker de formação refinada, com paixões junkerianas", que com seu "ódio mortal ao povo emergente", ao modo de uma "contorcida cabeça de Janus" posicionou-se na fronteira entre o antigo e o novo. ${ }^{32}$ Três anos depois, já familiarizado com as últimas sutilezas da metodologia de crítica textual em função de seus estudos filológicos com Friedrich Ritschl, Nietzsche submetia sua primeira publicação filosófica, Para a história da coleção de ditos de Teógnis (Zur Geschichte der Theognideischen Spruchsammlung) ao Rheinischen Museum für Philologie, que minuciosamente reconstruía a história da transmissão da poesia associada ao nome de Teógnis. O mesmo obstinado empenho se revela nas publicações de Nietzsche sobre Diógenes Laércio e suas fontes, mas também nos exemplares interfolhados de Ésquilo em sua biblioteca, o que dá provas do quanto Nietzsche lutava pela otimização da forma textual transmitida pelos clássicos gregos. No entanto, chama a atenção o fato de que, em seus ensaios, Nietzsche como filólogo jamais ter se aventurado pelos autores maiores da Antiguidade. Sua notável conferência de estreia na Basileia, Homero e a filologia clássica, aparece apenas como impressão particular e não aborda a filologia de Homero, mas o toma como ponto de partida de uma reflexão, assim como a filologia poderia se consolidar como uma ciência-guia e como uma arteguia de caráter abrangente. Mas com o tempo, o empoeirado e seco empreendimento de crítica textual não mais satisfez a

32 KGW I 3: 18[4], p. 469-470, cf. Jensen 2013, p. 12-23. Nietzsche retorna a Teógnis na Genealogia da moral I 5, onde, como faz ver Geuss 2011, p. 14-17, esboça o seu retrato. 
Sommer, A. U.

Nietzsche. Por atento que pudesse se mostrar a temas filológicos específicos, mais do que isso ele aspirava à amplidão, a uma visão de conjunto. A corroborar essa percepção está o fato de em sua biblioteca se ter conservada uma série de traduções de textos antigos - de Aristóteles, por exemplo, há uma tradução integral para o alemão em quatro volumes, apenas e justamente a Retórica estando em grego.

Também o primeiro livro de Nietzsche, frequentes vezes esquecido e que nem mesmo está na KGW, é puro fruto de leituras e modestamente chamado de Registerheft [Caderno de registros], um índex de 176 páginas sobre os volumes de 1 a 24 da nova série do Rheinischen Museum. Este livro, de quem ninguém nomeia o autor, foi elaborado por Nietzsche ao longo de alguns anos a pedido de Ritschl. Para tanto ele se ocupou de 15 mil páginas de filologia, com o material tendo sido minuciosamente explorado com vistas ao usuário do periódico. Pródigo em austeridade, se esse trabalho de leitura foi de grande utilidade para abastecer $O$ nascimento de tragédia com as ciências da antiguidade, também aí as demandas do ofício filológico devem ter exaurido Nietzsche além da conta. Não obstante, em que pese toda a sua simpatia pela psicologia e pelas ciências naturais, a filologia se manteve como paradigma não apenas da boa leitura, mas também, em se tratando de ciência, fez-se linha-mestra para o filósofo até em sua produção tardia. ${ }^{33} \mathrm{O}$ que se tem é Nietzsche a dali em diante recobrir os meros "eruditos" com escárnio e zombaria.

4. O leitor da cultura. Ao modo de contrapeso às leituras resultantes de uma demanda profissional, o jovem professor tinha à disposição não apenas os clássicos mais recentes da literatura alemã e estrangeira, os quais ele se aprazia em citar de passagem em seus primeiros escritos filosóficos - muitas

33 A esse respeito, de maneira pormenorizada, $c f$. Benne 2005.

32 | Cad. Nietzsche, Guarulhos/Porto Seguro, v.40, n.1, p. 9-43, janeiro/abril, 2019. 
vezes de segunda mão. Contrapeso igualmente forte lhe eram as leituras de contemporâneos seus que ambicionavam uma reforma da cultura - em primeiro lugar, e em especial, dos escritos de Richard Wagner. Eletrizado pelo contato pessoal com Wagner, a não ser no caso de citações diretas muitas vezes não é possível decidir onde o jovem entusiasmado efetivamente leu Wagner e onde tomou a palavra ouvida do mestre como revelação, vindo a incorporá-la. De qualquer modo, em 1869 Nietzsche enviou para revisão e impressão a primeira parte da autobiografia de Wagner, Mein Leben [Minha vida], como iniciativa particular. A consciência de que a cultura contemporânea estava a demandar uma remodelação profunda era algo que Nietzsche podia encontrar também em outros autores, dos quais ele tomava distância. Se Paul de Lagarde, com seu programa nacionalista radical, era por ele avidamente lido, mas raramente citado, ${ }^{34}$ a David Friedrich Strauss, com seu extraordinariamente bem-sucedido A crença antiga e a nova (Der alte und der neue Glaube), por incentivo de Wagner ele dedicou a primeira das Considerações extemporâneas. Com isso manteve Strauss em sua mira como "escritor", citando-o em páginas e páginas, podendo trazer à luz uma miríade de problemas estilísticos. A leitura se lhe tornava ali arma de polemização - o que se tem é um ler contra, um ler contraa-corrente, a fim de ele próprio se distinguir pela escrita, livrar-se de concorrentes importunos e garantir para si uma prerrogativa de interpretação da sua atualidade. Nesse caso, a leitura precisa aparece mesclada ao veneno.

5. O leitor explorador do mundo e criador do mundo. Quanto mais Nietzsche passava a se manifestar como filósofo autônomo, quanto mais buscava se emancipar de Wagner, com tanto

34 Cf. Sommer 1998b. 
Sommer, A. U.

mais força ele se diferenciava de suas esferas de leitura. Com isso, tornava-se cada vez mais autoconsciente dos limites da disciplina e da linguagem, a fim de absorver avidamente o que lhe parecia adaptado ou adaptável a si próprio. Mesmo diferenças qualitativas importavam-lhe pouco: por um lado, com Emil Du Bois-Reymond e Ernst Mach no campo das ciências da natureza, ou com Julius Wellhausen no campo do Antigo Testamento, ele travava conhecimento com autores que representavam o state of the art de então. Por outro, com Os legisladores religiosos. Manu, Moisés, Mahomé (Les législateurs religieux. Manou. Mö̈se, Mahomet [1876]) de Louis Jacolliot, ele se valia de um desolador arremedo antissemita para atestar suas projeções de desejo de um ordenamento de castas de caráter filosófico no Código legal do Manu, do antigo hinduísmo - arremedo este que um primeiro olhar do filólogo crítico teria bastado para desmascarar. ${ }^{35}$ Mas é óbvio que isso o agradou a ponto de não suscitar sua suspeita profissional.

Uma pergunta importante em todo esse contexto versa sobre como Nietzsche na verdade chegou a suas leituras. Por certo que recomendações que se lhe faziam em contato pessoal ou por carta exerceram aí seu papel. Por certo que o indólogo Paul Deussen e o sanscritista Erns Windisch, ambos colegas de escola e de pesquisa, teriam-no dissuadido vivamente de Jacolliot. Assim sendo, não se trata de imaginar que os livros dão à luz tão-somente a si próprios, mas eles conduzem também a outros livros - ou a para além deles. $\mathrm{Na}$ Introdução à ciência comparativa da religião (Einleitung in die vergleichende Religionswissenschaft), de Max Müller, obra que Nietzsche tomou de empréstimo da biblioteca da Universidade da Basileia, ${ }^{36}$ há um juízo aniquilador sobre Jacolliot. Em se tratando da

35 Cf. Sommer 2012a, p. 368.

36 Cf. Crescenzi 1994, p. 435.

34 Cad. Nietzsche, Guarulhos/Porto Seguro, v.40, n.1, p. 9-43, janeiro/abril, 2019. 
exploração de novas razões e abismos livrescos, as visitas a bibliotecas e livrarias foram um fator importante. E ali encontravam-se ainda - campo amplamente inexplorado - os periódicos e jornais pelos quais Nietzsche podia ficar sabendo de acontecimentos culturais, mas sobretudo também podia obter indicações de leituras preciosas. Para tanto ele consultava não apenas a muito conceituada Revue des deux mondes e o Journal des Débats, mas algumas vezes também o jornal conservador prussianno Kreuzzeitung.

Algumas indicações do cosmos literário de Nietzsche, que não se deixam enquadrar em categorizações, devem concluir o mapeamento que se pretendeu aqui.

a. Filosofia. Ainda que Nietzsche desde o início dos anos 1870 se entendesse filósofo, ele quase não se ocupava de leituras propriamente filosóficas. Exceção feita a Platão, tomava contato com os clássicos da filosofia sobretudo por meio de compêndios de história da filosofia. E juntamente com Schopenhauer, serviço inestimável lhe prestou um segundo filósofo que lhe foi de grande importância: Friedrich Albert Lange com seu História do materialismo. Na segunda metade da década de 1870, autores franceses do período iluminista e moralistas do século XVII passaram a receber sua atenção, enquanto já desde cedo, com Emerson, ele se aproximara da filosofia em língua inglesa sob traduções alemãs, como mais tarde então faria com decidida relutância - com John Stuart Mill e Spencer. Entre os contemporâneos de língua alemã, além de Eugen Dühring, Eduard von Hartmann, Paul Rée e Drossbach, foram de especial importância Otto Liebman, Gustav Teichmüller e African Spir - pano de fundo para rejeições vigorosas em meio a adesões implícitas.

b. Ciências da natureza, medicina e psicologia. Se Nietzsche em seus tempos de juventude manteve-se a todo tempo alheio 
Sommer, A. U.

às ciências da natureza, como professor da Basileia já se viu tomado de um forte interesse por elas, calcado sobretudo na vontade de fazer com que seu filosofar no âmbito das ciências do espírito pudesse conquistar adesões fora desse âmbito. Por isso, retirou da biblioteca da universidade o Philosophiae naturalis theoria redacta (1759) de Ruggiero Giuseppe Boscovich, cujo antiatomismo e antimaterialismo foram-lhe muito conveniente em sua luta contra o dogmatismo (não apenas em ciências naturais), e esse conhecimento ele também empregou na luta contra a "atomística da alma" (JGB/BM 12, KSA 5.27). Além disso Nietzsche tomou parte nos debates de seu tempo sobre a teoria da evolução, mas sem ter lido Darwin no original. Nisso lhe foi conveniente um crítico de Darwin como William Henry Rolph, com cujo auxílio ele pôde substituir o impulso à autoconservação e à luta por recursos escassos pela superação de si e pela luta por potência. E também Johann Gustav Vogt proporcionou a Nietzsche material para a sua concepção de potência, enquanto o astrônomo Johann Friedrich Zöllner alimentou o pensamento do eterno retorno e Angelo Secchi fez as vezes de garante das questões astronômicas.

Na biblioteca de Nietzsche, a medicina é representada por uma série de guias de clínica geral, que o filósofo adquiria sobretudo para fins de sua própria terapêutica. E tendo assumido o olhar psicológico como a sua via de acesso específica para problemas filosóficos, fêlo sem tomar conhecimento do amplo escopo da literatura em que a psicologia se constituía como disciplina. No entanto, lia autores como Henry Maudsley, Francis Galton e Harald Höffding, ao passo que sua análise madura do processo de degenerescência e decadência como fenômeno social e cultural dominante deu-se por um lado pelos trabalhos psiquiátricos de Charles Féré, e por outro por meio de estudos psicológicos em literatura de Bourget. Também aqui

36 | Cad. Nietzsche, Guarulhos/Porto Seguro, v.40, n.1, p. 9-43, janeiro/abril, 2019. 
Nietzsche se mostrou altamente seletivo, com uma prática de leitura centrada em suas próprias prioridades.

c. História, etnologia, economia, política. O filosofar experimental de Nietzsche é decidiamente um filosofar histórico, que problematiza todos os compromissos supra-históricos em suas pretensões de validade. Em conformidade com essa postura, Tucídides o fascinou desde o início ${ }^{37}$ em conformidade com isso, Jacob Burckhardt e Franz Overbeck cativaram-no não apenas pela via da amizade e do pessoal, mas também com suas obras de caráter histórico; em conformidade com isso, a visão de conjunto das obras de William Edward Hartpole Lecky e Hippolyte Taine não deixou de influenciá-lo. Manuais como A ética dos antigos gregos (Die Ethik der alten Griechen), de Leopold Schmidt. ou o Manual de moral (Handbuch der Moral), de Johann Julius Baumann, fizeram frente à rápida necessidade de informações, que se tornou extensiva ao campo da etnografia - ciência que Nietzsche buscou porque lhe oferecia a possibilidade de perspectivar o europeu de forma crítica e de um ponto de vista externo - e extensiva também à economia (onde se tem, por exemplo, o Cultura e natureza [Cultur und Natur], 1887, de Emmanuel Hermann). Na economia de leitura de Nietzsche, papel muito menor já desempanhavam os livros sobre política. Salta aos olhos, em especial, não haver menção alguma ao nome de Karl Marx, muito menos a alguma vez o ter lido, muito embora constantemente ouvisse falar em socialismo. Além dos jornais, o socialismo chegava até ele pela via de fontes secundárias - como pelo A mulher no passado, presente e futuro (Die Frau in der Vergangeheit, Gegenwart und Zukunf, 1883), de August Bebel.

37 Cf. Geuss 2008 e Sommer 2012, p. 569-571. 
Sommer, A. U.

d. Beletrística. Se da literatura de seu tempo em língua alemã, exceto pelos casos de Adalbert Stifter e Gottfried Keller, Nietzsche possuía conhecimento apenas marginal, nos anos 1880 foi de maneira plástica que teve diante dos olhos a produção literária estrangeira, mais precisamente a de proveniência francesa e russa. Por certo que estudos críticos de literatura, como os de Bourget, Ferdinand Brunetière, Jules Lemaître e Émigle Bérard-Varagnac pouparam-lhe o esforço de ler os autores em questão no original. Leituras intensivas da obra original podem ser comprovadas sobretudo no caso de Stendhal, mas também em Tolstói (Ma religion, 1885) e Dostoiévski - e para esses últimos, os trabalhos de mediação de Eugène-Melchior de Vogüé podem ter sido essenciais. Raramente Nietzsche lia algo por puro e simples prazer prazer que lhe proporcionavam os humoristas americanos, Mark Twain mais do que todos. Em vez disso, a beletrística provia-lhe abundante material preparatório para o tratamento filosófico do que em seu tempo estava em questão - e do que não estava em questão.

e. Nietzsche como leitor de si mesmo. Se se perguntar agora que tipo de leitor foi Nietzsche, será o caso de por fim se perguntar como ele leu a si mesmo. Afinal de contas, ele se ocupou continuamente de seus próprios escritos. Poder-se-ia dizer que a sua relação com eles seria mais íntima e emocional do que com a maioria das obras que de outro modo ele tivera diante de si. Tornar a ler o Assim falava Zaratustra era algo que lhe rendia convulsões: "Com ele fiz à humanidade o maior presente que até agora lhe foi feito. Esse livro, com uma voz de atravessar milênios, é não apenas o livro mais elevado que existe, autêntico livro do ar das alturas - o inteiro fato homem acha-se a uma imensa distância abaixo dele -, é também o mais profundo" (EH/EH "Prólogo" 4, KSA 6.259). E em

38 | Cad. Nietzsche, Guarulhos/Porto Seguro, v.40, n.1, p. 9-43, janeiro/abril, 2019. 
meio a todo esse êxtase, que o faz sair do próprio controle no trato com o Zaratustra: quase ao mesmo tempo, em Nietzsche contra Wagner ele pôde se valer de seus escritos anteriores ao modo de mina e depósito de material. Portanto, também no Nietzsche como autoleitor suas práticas de leitura e não-leitura são multivariegadas.

Se Nietzsche leu, leu a fim de poder poder pensar e escrever. Se não leu, ele não leu - igualmente a fim de poder pensar e escrever.

\title{
What Nietzsche read and what he did not read
}

\begin{abstract}
The main purpose of this article is to explore the complex and multifarious condition of Nietzsche as a reader. Thus, in the first place the text clarifies the various character of informations about reading, not always reliable, expressed in his very work, in the notebooks, in the letters, by testimony of third parties, in his preserved library and in the not preserved library, in purchases and in borrowing from libraries. At a second moment, the article put forward reading phases since the very young Nietzsche, reading strategies, his freeing process and his self-stilization as a reader. In the scope of reading spheres, the article adresses Nietzsche as a philology reader so much as a reader of scientific texts, and a reader of the world, of culture. Lastly, on questioning how Nietzsche became a reader of himself, the text nods to the question of how his attitude towards reading devolves into a way of thinking and reading his very work, in this manner asserting the initial claim, namely, to understand Nietzsche the philosopher we must bear in mind whom is he talking to.
\end{abstract}

Keywords: reader, sources, Nietsche's library, culture.

\section{Referências bibliográficas}

BENNE, Christian. Nietzsche und die historisch-kritische Philologie. Berlim e Nova Iorque: Walter de Gruyter, 2005.

BROBJER, Thomas H. "Nietzsche's Reading and Private Library, 1885-1889". In: Journal of the History of Ideas 58, 1997, pp. 663-693. 
Sommer, A. U.

BROBJER, Thomas H. "Nietzsche's Education at the Naumburg Domgymnasium 1855-1858,”. IN: Nietzsche-Studien, 28, 1999, pp. 302-322

BROBJER, Thomas H. "A Discussion and Source of Hölderlin's Influence on Nietzsche, Nietzsche's Use of William Neumann's Hölderlin,". In: NietzscheStudien, 30, 2001, pp. 397-412.

BROBJER, Thomas H. Nietzsche’s Philosophical Context. An Intellectual Biography. Urbana e Chicago: University of Illinois Press, 2008.

BROCHARD, Victor, Les sceptiques grecs. Paris: Imprimerie Nationale, 1887.

CAMPIONI, Giuliano. "Die, ideelle Bibliothek Nietzsches'. Von Charles Andler zu Mazzino Montinari,". In: Knoche, Michael and others (eds.) Zur unterirdischen Wirkung von Dynamit. Vom Umgang Nietzsches mit Büchern zum Umgang mit Nietzsches Büchern. Wiesbaden: Harrasowitz, 2006, pp. 133-142

CAMPIONI, Giuliano/D'Iorio, Paolo/Fornari, Maria Cristina/Fronterotta, Francesco/ Orsucci, Andrea (org.). Nietzsches persönliche Bibliothek. Berlim: Walter de Gruyter), 2003.

CRESCENZI, Luca. "Verzeichnis der von Nietzsche aus der Universitätsbibliothek in Basel entliehenen Bücher (1869-1879)," Nietzsche-Studien, 23, 1994, pp. $388-442$

D'IORIO, Paolo. "Les livres français de la bibliothèque de Nietzsche". In: Le Rider, Jacques (eds.), Nietzsche. Cent ans de réception française. Paris: Editions Suger, 1999, pp. 9-30.

DROSSBACH, Maximilian. Ueber die scheinbaren und die wirklichen Ursachen des Geschehens in der Welt (C.E.M. Pfeffer), 1884.

FIGL, Johann, Dialektik der Gewalt. Nietzsches hermeneutische Religionsphilosophie. Mit Berücksichtigung unveröffentlichter Manuskripte. Düsseldorf : Patmos, 1984.

. Nietzsche und die Religionen. Transkulturelle Perspektiven seines Bildungsund Denkweges. Berlim: Walter de Gruyter, 2007.

FISCHER, Kuno. Geschichte der neuern Philosophie. Bde. 3 und $4=$ Immanuel Kant. Entwicklungsgeschichte und System der kritischen Philosophie. Bd. 1: Entstehung und Begründung der kritischen Philosophie. Die Kritik der reinen Vernunft. Bd. 2: Das Lehrgebäude der kritischen Philosophie. Das System der reinen Vernunft. Mannheim: Friedrich Bassermann, 1860.

$40 \mid$ Cad. Nietzsche, Guarulhos/Porto Seguro, v.40, n.1, p. 9-43, janeiro/abril, 2019. 
FISCHER, Kuno. Geschichte der neuern Philosophie. Bd. 1: Descartes und seine Schule. 1. Theil: Allgemeine Einleitung. René Descartes. 2. Theil: Descartes' Schule. Geulinx. Malebranche. Baruch Spinoza. Zweite völlig umgearbeitete Auflage. Mannheim: Friedrich Bassermann, 1865.

. Geschichte der neuern Philosophie. Bde. 3 und $4=$ Immanuel Kant und seine Lehre. Erster Theil: Entstehung und Begründung der kritischen Philosophie. Zweiter Theil: Das Vernunftsystem auf der Grundlage der Vernunftkritik. Dritte neu bearbeitete Auflage. Heidelberg: Carl Winter, 1889.

FORNARI, Maria Cristina. "I libri di Friedrich Nietzsche. Vicende di una biblioteca d'autore". In: Meschini, Franco A. (org.), Le opere dei filosofi e degli scienziati. Filosofia e scienza tra testo, libro e biblioteche. Florença: Casa Editrice Leo S. Olschki), 2011, pp. 205-219

GEUSS, Raymond. "Thucydides, Nietzsche, and Williams," in: Dries, Manuel (org.): Nietzsche on Time and History. Berlim: Walter de Gruyter, 2008, pp. 35-50.

GEUSS, Raymond. "The Future of Evil", in: May, Simon (org.), Nietzsche's On the Genealogy of Morality. A Critical Guide. Cambridge: Cambridge University Press, 2011, pp. 12-23.

HÖDL, Hans Gerald. Der letzte Jünger des Philosophen Dionysos. Studien zur systematischen Bedeutung von Nietzsches Selbstthematisierungen im Kontext seiner Religionskritik. Berlim: Walter de Gruyter, 2009.

JANZ, Curt Paul. Friedrich Nietzsche. Biographie: Munique, Hanser, 1978.

JENSEN, Anthony K. Nietzsche's Philosophy of History. Cambridge : Cambridge University Press, 2013.

LASKA, Bernd A. "Nietzsches initiale Krise. Die Stirner-Nietzsche-Frage in neuem Licht” In: Germanic Notes and Reviews 33/2, 2002, pp. 109-133

LEHMANN, Christoph. Blumengarten, frisch ausgejätet, aufgeharkt und umzäunt von einem Liebhaber alter deutscher Sprache und Weisheit. Berlim: C. Duncker, 1879.

MONTINARI, Mazzino. Nietzsche lesen. Berlim: Walter de Gruyter, 1992. . "Zum Verhältnis Lektüre - Nachlaß - Werk bei Nietzsche". In: Studia Nietzscheana 2014, http://www.nietzschesource.org/SN/m-montinari-2014b. 
Sommer, A. U.

NIETZSCHE, Friedrich. Sämtliche Briefe: Kritische Studienausgabe (KSB). Berlin/ New York: Walter de Gruyter, 1986.

. Sämtliche Werke. Kritische Studienausgabe (KSA). Berlin/New York: Walter de Gruyter, 1999.

. Der Wille zur Macht. Zweite Fassung = Nietzsche's Werke. Vol. 15 and 16. Leipzig: Alfred Kröner, 1911.

OVERBECK, Ida. "Erinnerungen an Friedrich Nietzsche," in: Carl Albrecht Bernoulli (org.), Franz Overbeck und Friedrich Nietzsche. Eine Freundschaft, vol. 1 (Diederichs), 1908, pp. 234-251

SAINTE-BEUVE, Charles-Augustin. Menschen des XVIII. Jahrhunderts. Übersetzt von Ida Overbeck, initiiert von Friedrich Nietzsche. Mit frisch entdeckten Aufzeichnungen von Ida Overbeck neu ediert von Andreas Urs Sommer. Berlim: Die Andere Bibliothek, 2014.

SCANDELLA, Maurizio. "Did Nietzsche Read Spinoza? Some Preliminary Notes on the Nietzsche-Spinoza-Problem, Kuno Fischer and Other Sources". In: Nietzsche-Studien, 41, 2012, pp. 308-332.

SCHANK, Gerd. "Rasse" und "Züchtung" bei Nietzsche. Berlim: Walter de Gruyter, 2000.

SOMMER, Andreas Urs. "Augustinus bei Franz Overbeck. Ein Rekonstruktionsversuch". In: Theologische Zeitschrift, 54, 1998a, pp. 125-150.

. "Zwischen Agitation, Religionsstiftung und ,Hoher Politik'. Friedrich Nietzsche und Paul de Lagarde". In: Nietzscheforschung 4, 1998b, pp. 169194.

. "Nietzsche und die Bibel. Forschungen und Desiderate," Jahrbuch für Internationale Germanistik 40, 2008, pp. 49-64.

. Kommentar zu Nietzsches Der Fall Wagner. Götzen-Dämmerung = Historischer und kritischer Kommentar zu Friedrich Nietzsches Werken, hg. von der Heidelberger Akademie der Wissenschaften, Bd. 6/1 (Walter de Gruyter), 2012a.

. "Nietzsche's Readings on Spinoza. A Contextualist Study, Particularly on the Reception of Kuno Fischer". In: Journal of Nietzsche Studies 43/2, 2012b, pp.156-184

42 | Cad. Nietzsche, Guarulhos/Porto Seguro, v.40, n.1, p. 9-43, janeiro/abril, 2019. 
. Kommentar zu Nietzsches Der Antichrist. Ecce homo. Dionysos-Dithyramben. Nietzsche contra Wagner = Historischer und kritischer Kommentar zu Friedrich Nietzsches Werken, hg. von der Heidelberger Akademie der Wissenschaften, Bd. 6/2 (Walter de Gruyter), 2013a.

. "Nietzsche, Friedrich," in Pollmann, Karla (org.), The Oxford Guide to the Historical Reception of Augustine. Oxford: Oxford University Press, 2013b, pp. $1450-1452$

TREIBER, Hubert, “,Das Ausland" - die ,reichste und gediegenste Registratur" naturwissenschaftlich-philosophischer Titel in Nietzsches, idealer Bibliothek". In: Nietzsche-Studien 25, 1996, pp.394-412.

Artigo recebido para publicação em 05/01/2019.

Artigo aceito para publicação em 16/02/2019. 